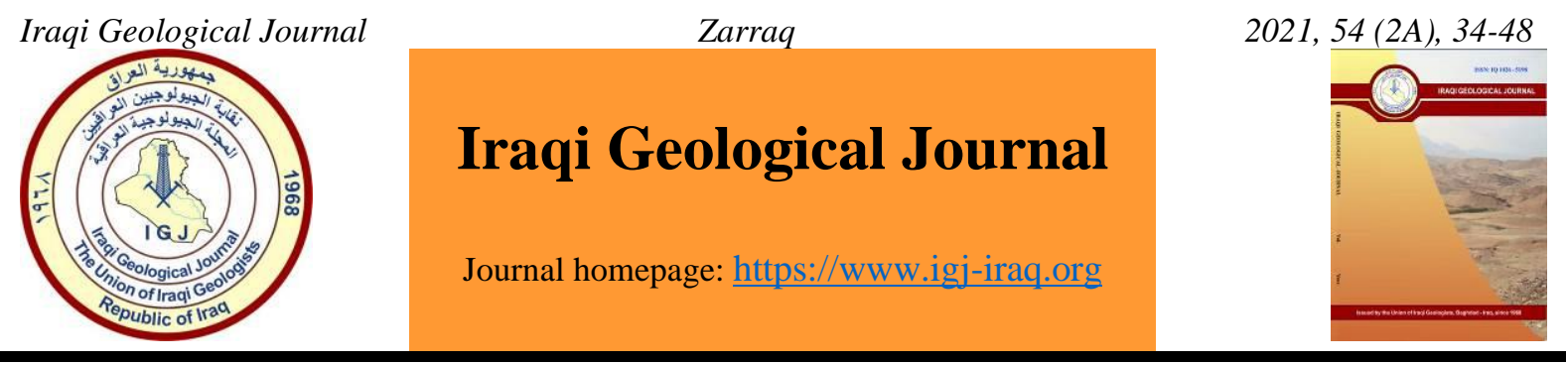

\title{
Slope Stability Analysis of the Southwestern Limb of Kosret Anticline in Dokan, Northeastern Iraq
}

\author{
Ghazi Atiya Zarraq1,* \\ ${ }^{1}$ Department of Applied Geology, College of Science, Tikrit University, Tikrit, Iraq \\ * Correspondence: ghazi.zarraq@tu.edu.iq
}

Received: 1 April 2021; Accepted: 3 May 2021; Published: 31 July 2021

\begin{abstract}
The stability of the rock slopes was studied on the southwestern limb of the Kosret Anticline in the Dokan Area in northeastern Iraq to analyze and indicate the danger of rock mass failures along the public street linking Dokan and Quesangaq, Erbil and the road which link between the city and the residential neighborhood of Dokan Lake, as well as the revealing and the analysis of the risk of landslides in the slopes and rocks detectors of exposed rocks of the formations in the study area. The stereographic projection was used in the analysis and classification of the rock slopes. This study has shown that the failures of rocks are fall and day lighting bedding plane. The factors that affect the stability of the slopes were assessed. This research mainly focuses on identifying the types of collapses along the rocky slopes and the factor that affects the instability of the studied slopes. It was found that it is the direction slopes and the interruption geometry. Different treatment methods have been proposed for the studied rock base on the rock slope analysis. The expected failure types that may occur along the road are plane sliding, rock fall, toppling, and probably the failure type in the future may be planner sliding due to the angle of the friction comes to zero degree. The rocky slopes along the road require constant monitoring due to their hazardous conditions. Where it was found that the attitude of the joints and their frequency with the relation between the attitude of the slopes and the rock beds played an important role in the failures, as well as the weak rocks of the Marl layers of the Shiranish, Kometan and Tanjero formations play a key role in responding to weathering and erosion factors that increase the failures of rock slopes.
\end{abstract}

Keywords: Slope stability; Rock slope; Kosret Anticline; Dokan

\section{Introduction}

The Dokan area has an important geographic location as it is considered the junction of several roads linking the province of Sulaymaniyah with the northern cities of Rania, Qwaisanjaq, and Erbil, as well as the presence of the Dokan Dam and Dokan Basin, which have geologically and structurally important features. Dokan is located on the southwestern limp of the Kosret Anticline, which is characterized by its dense topographic slopes and deep valleys, due to the exposure of clastic sediments that are unable to resist the weathering and natural erosion processes. Most of the previous studies in northern Iraq were carried out on the proposed road included, which found in different geological subjects such as; Structural geology, sedimentological, stratigraphic and geomorphological features (Qader et al., 2020). Moreover, this anticline has a relatively high tendency to dip towards the southwest

DOI: $\underline{10.46717 / i g j .54 .2 A .3 M s-2021-07-24 ~}$ 
direction, as well as the highly differentiations of the geological lithology formations in the study area (Jassim and Goff, 2006). The study and analysis of the rock slope stability are of great importance and a key role in terms of its widespread in nature, which is the basis of all the geomorphological features on the surface, which have a direct impact on transportation, engineering and civil installations, quarries and surface, and sub-surface mines as well as the safety and stability of dams and reservoirs. The material characteristics of a rock slope, the height, the face angle, and the discontinuity orientations play a great role in the instability problem of road and slopes (Qader et al., 2021). The study area included most of the rocky slopes surrounding the Dokan dam and the roads linking Dokan to the surrounding towns, specifically the exposed formation of Qamchuqa, Kometan, Shiranish, Tangero, Kolosh, Sinjar, Gercus, Avana, and Pilaspi. The studied area is located between the easting direction (490000) (505000) and northing direction (3976000) (3984000) (Fig. 1).

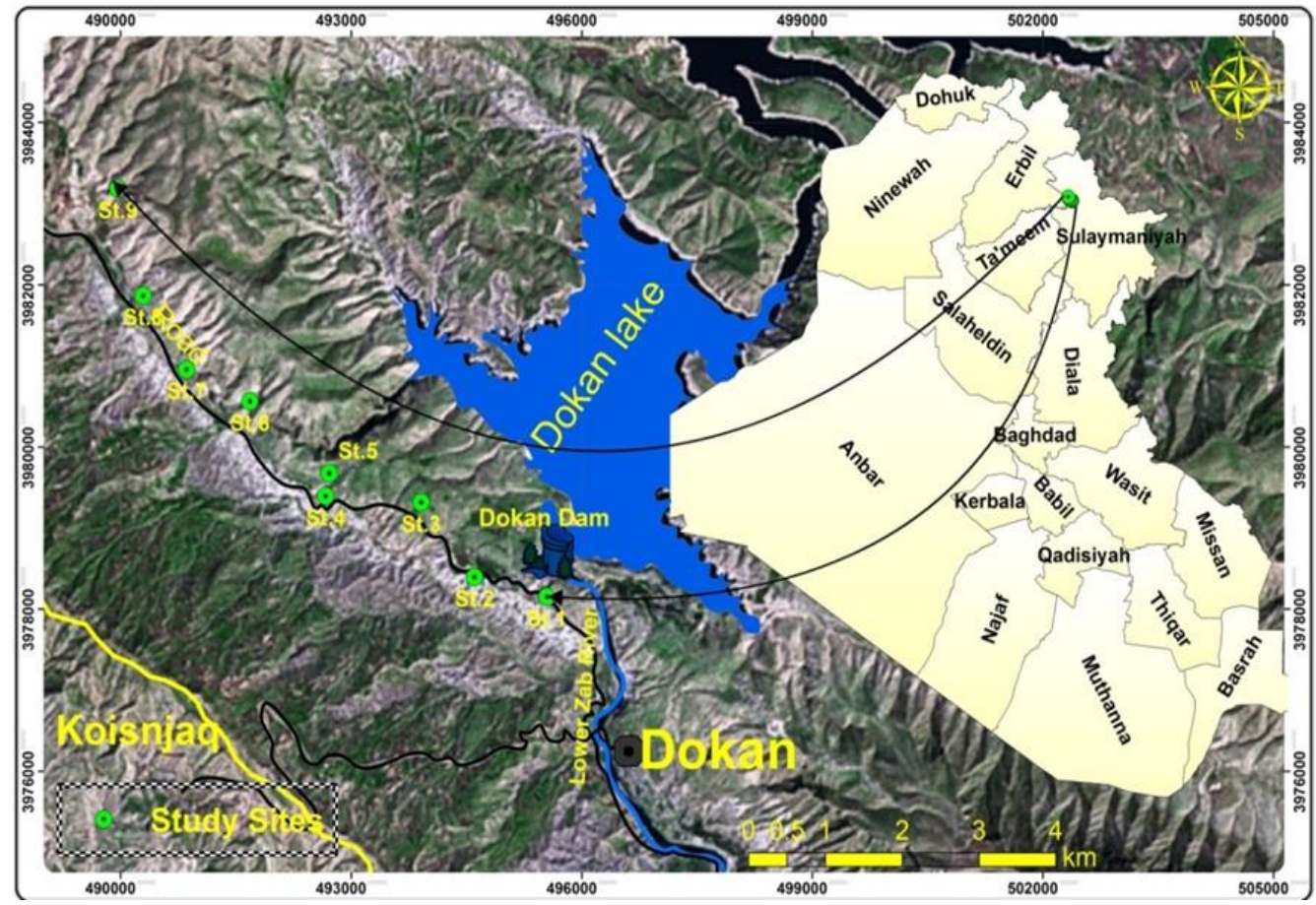

Fig. 1. Location map of the study area

The most important factors affecting slope stability are the natural factors that include geomorphological factors, the structural situation of the area, weathering and erosion factors as well as seismic activity (Hoek and Bray, 1981). The factors that come from industrial activities include the operations of surface mines, quarries, road construction, and urban expansion in the rugged and highlands. The aim of this study is to determine the discontinuities of the rocks, as well as their classification according to the position of the layers. A stereoscopic projection diagram was drawn for the field measurements that represent the direction, value of the inclination of the discontinuities and the bedding plane, failure movement zone, and calculation of the angle of friction of the rock with the description of the characteristics of rock slopes and their classification for the purpose of opening roads, construction of engineering projects, and industrial mining processes.

\section{Materials and Methods}

This study has been fulfilled by two dimensions, which are: 


\subsection{The Fieldwork}

It includes the following procedure:

- Several field trips are conducted in which a detailed survey of the type of the engineering and structural rock slopes was carried out.

- The station locations are selected where the rock formations are exposed and intersected with the transportation roads and the engineering and civil installations using the GPS device as well as the naming of the geological formation that it includes as shown in (Table 1).

- The attitude of slopes, beddings and discontinuities (dip direction and dip amount) are measured.

- Formations lithology are described geometrically according to the report proposed by the Geological Working Group of the Engineering Group of the Geological Society of London (A), (Anon, 1972), as well as the rock description proposed by Hawkins (Hawkins, AB, 1986).

- A comprehensive survey of the existing discontinuity is conducted, including attitude, frequency, spacing and its spread on the surface of the persistence.

- The types of failures that were occurred and supposed are studied.

- Rock samples from each station were collected depending on variability in rocks lithology for study and laboratory tests (Table 1).

Table 1. The Stations Location

\begin{tabular}{lccc}
\hline Station No. & Easting & Northing & Elevation (a.s.l.)m \\
\hline St.1 & 495550.00 & 3978150.00 & 440.00 \\
St.2 & 494608.00 & 3978394.00 & 588.00 \\
St.3 & 493912.62 & 3979315.86 & 575.00 \\
St.4 & 492669.00 & 3979395.00 & 550.00 \\
St.5 & 492718.00 & 3979675.00 & 617.00 \\
St.6 & 491684.00 & 3980563.00 & 634.00 \\
St.7 & 490861.25 & 3980955.17 & 615.00 \\
St.8 & 490295.93 & 3981865.90 & 550.00 \\
St.9 & 489968.00 & 3983186.00 & 678.00 \\
\hline
\end{tabular}

\subsection{Office and laboratory Work}

It is known that the laboratory tests of mechanical, dynamic and static rocks and soil are great importance in the study and analysis of the stability of rock slopes. This study includes the following office and laboratory studies:

- Data are represented using a stereographic projection technique to determine the type and nature of failure in rock slope or potential occurrence in the study area using the (Geo Orient 9.2) software.

- Unconfined compressive strength is examined to classify rocks geometrically.

- Direct shear test is performed for the purpose of identifying and determining the degree of soil cohesion and the internal friction angle of the soil.

The degree of soil cohesion can be used to analyze all types of rock collapse. The angle of internal friction is great importance in the study of the type of failures like plane sliding and wedge sliding. The following symbols are used in the data representation as in (Table 2). 
Table 2. The Symbols used in data representation

\begin{tabular}{ll}
\hline Parameters & Symbols \\
\hline Internal friction angle & $\varnothing$ \\
The great angle of persistence & $\mathrm{S}$ \\
Discontinuity of Set 1 & $\mathrm{J} 1$ \\
Discontinuity of Set 2 & Plane sliding occurred \\
Plane sliding may be occurred & \\
Rock fall occurred & \\
Rock fall may be occurred & Toppling occurred \\
Toppling may be occurred \\
Wedge sliding occurred \\
Wedge sliding may be \\
occurred
\end{tabular}

\subsection{Geological Setting and Stratigraphy}

The Kosret Anticline represents one of the high folded zone structures in the northeastern of Iraq. It extends north-west-south-east at a distance of about $85 \mathrm{~km}$ and a width of $5 \mathrm{~km}$. Kosret anticline consists of double plunging, the first one is in the southeast direction, extends along the main road between Dokan city and the city center of Sulaymaniyah. The second is northwest extends towards the village of Qalat, which extends along the road leading to the city of Rania, in an en echelon relationship with the southeastern plunge of the Khalikan anticline. The geological formation in the study area and the stratigraphic sequence are conducted in the southwestern limp of Kosret anticline. The stratigraphic sequence of the Kosret Anticline is shown in Fig. 2, which drown using (Rockwork-15) software.

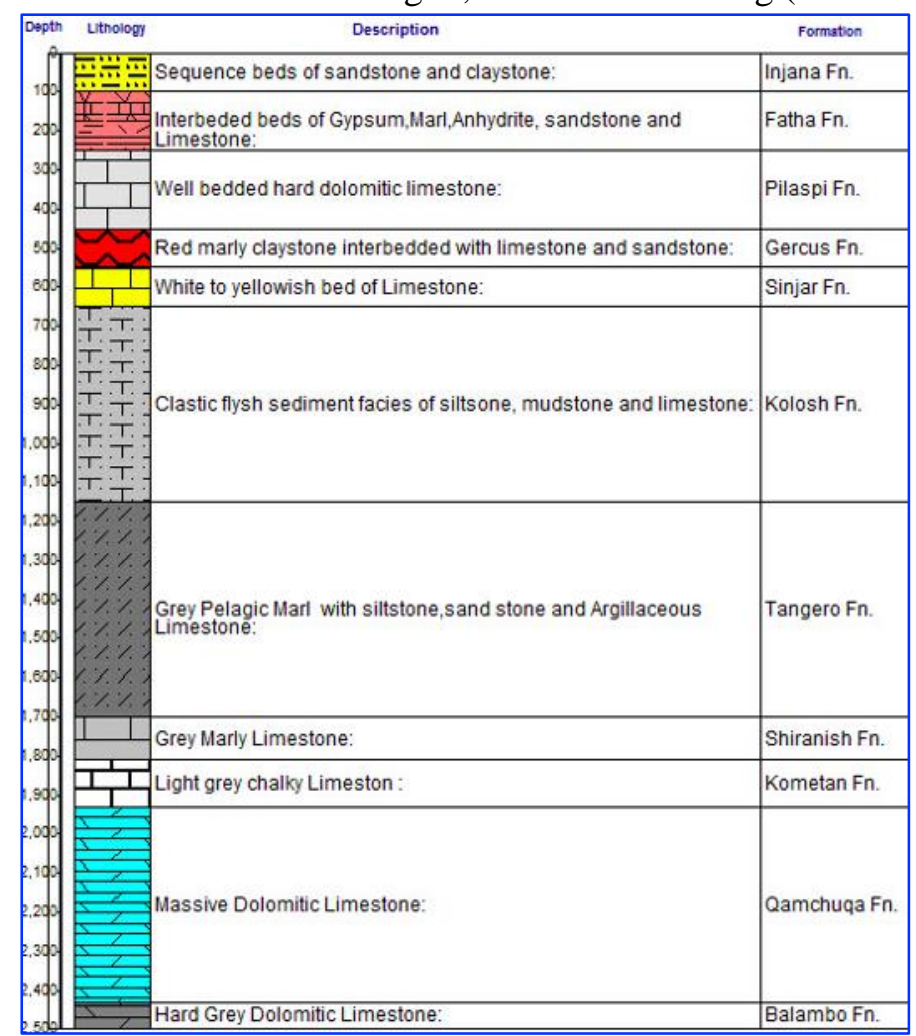

Fig. 2. Stratigraphic Column of Kosret Anticline 


\subsection{The Rock Description of the Formations}

- Balambo Formation (Valanginian): This formation consists of two types of layers, the Lower Balambo Formation of thin-bedded blue ammonitiferous limestone with intercalation of olivegreen marls and dark blue shale. The Upper Balambo Formation is composed of a monotonous sequence of thin-bedded globigerinal, passing downwards to radiolarian limestone. (Al-Dulaimi, and Thamer, 2008). Balambo Fn, represents the core of Kosret anticline which appear in the deep valleys that pour into the Dokan lake north-east of the city of Dokan.

- Qamchuqa Formation (Hauterivinian-Albian): This formation is composed mainly of very thick layers of massive dolomitic limestone, in a gray-color, containing of chert nodules. The thickness of the formation is about 500 meters (Jassim and Goff, 2006). The Precipitation environment is Ramp carbonate, which appears in the core of Kosret Anticline, while the upper limit of formation is unconformable with Komitan formation due to the loss of the Cenomanian Era, the lower limit is conformable with Balambo Fn. The most important part of this formation lies in the body of the Dokan Dam, due to its strong, cohesive and non-permeable rocks (Fig. 3).

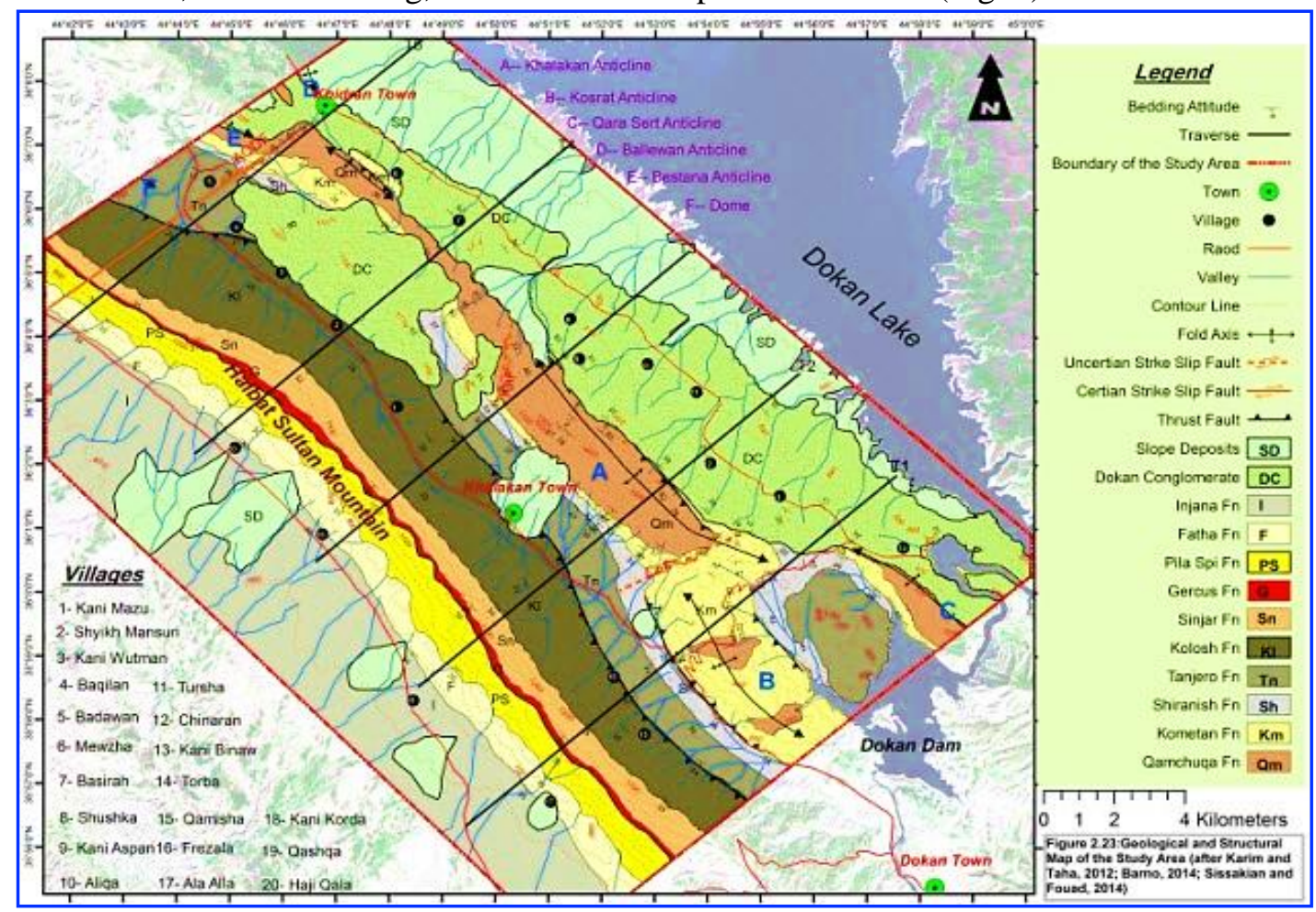

Fig. 3. Geological map of the study area (Ward, 2018)

- Kometan Formation (Turonian): This formation consists of thin to medium bedded, highly fractured, light grey or white limestone. It contains locally chert nodules or ribbons with rare pyrite concretions in the upper part of the formation. (Asaad, 2014). This formation has a stylolite phenomenon (Fig. 4) which is a rugged melting in layers produced by the pressure exerted on the layers after sedimentation, consolidation and deep landfill. The thickness of Kometan Formation in the study area is estimated at 120 meters in light of field observations. Gloconite-colored lenses of green-grey color are observed at the top of Kometan Formation separating it from Shiranish Formation. The Kometan Formation also contains Chert nodules parallel to the surfaces of the layers. The bottom contact is not conformable with the Qamchuqa Formation because of the loss of Cenomanian era and the upper surface is not conformable with the Shiranish Formation. The environmental deposition is a deep Pelagic environment (Balaky, et al., 2016). 


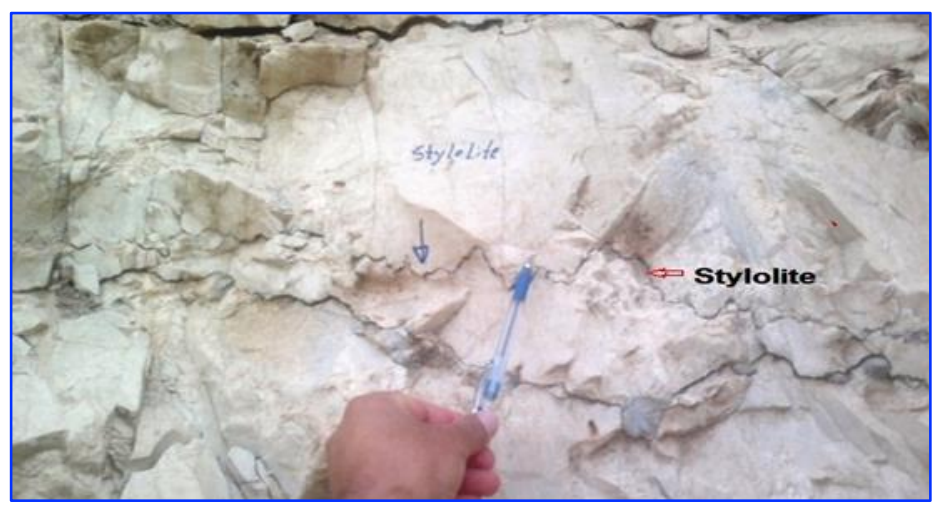

Fig. 4. The Stylolite phenomena in Kometan Fn.

- Shiranish Formation (Maastrichtian-Campanian): It consists of successive thin layers of marl and marly Limestone with calcite veins. Toward the top of the formation the thickness of the marly layers increases and the thickness of the marly Limestone layers decreases, so that the sedimentation environment approaches the areas where the sediments are abundant (Malak, 2015). The Shiranish Formation rocks are characterized by the phenomenon of exfoliation resulting from the effect of the folding operations. Moreover, it contains two systems of joints in two different directions, which increases the weakness of the upper rock layers of formation and makes it non-resistance to weathering and erosion processes. The formation thickness in the Dokan area is up to 110 meters. The lower contact is not conformable with Kometan formation, while the upper contact bed is conformable with Tanjero formation. The sedimentation environment is the Outer Shelf to Basinal Environment. (Al-Khafaf, 2005).

- Tanjero Formation. (Mastrichtian): The lithology of the Tanjero Formation consists of succession beds of sandstone, silt stone and marl stone. This formation consists of two parts, the lower part contains of clastic sandstone and siltstone rocks. The upper part consists of marl and Argillaceous Limestone interbedded with sandstone and conglomerates (Dunnington, 1953). The sandstone rocks contain chert nodules and pieces of igneous and metamorphic rocks. The thickness of the formation in the study area is about 550 meters. The sedimentation environment is a deep environment after a strong landing coincided with the Balambo-Tanjero Zone (Jassim and Goff, 2006). flysch Facies, which were formed by turbulent currents formed after lifting and mountain-building. The lower limit of the formation is conformable with the Shiranish Formation, while the top seam is not conformable with the Kolosh formation due to the loss of the Danian age, which represents the transition period from the Mesozoic Era to the Cenozoic Era. This formation and Kolosh Formation are distinguished by the absence of discontinuity levels being characterized by its clastic deposits, so it excludes the possibility of movements or rock collapses along the surface of discontinuity. Due to its weakly deposits, they are subject to weathering and erosion processes, which are so-called Raveling processes (Maerz, 2000), when the water permeates the pores, reducing the strength of the cohesion and thus obtaining the processes of fragmentation and destruction of these rocks.

- Kolosh Formation (M. Paleocene): This formation consists of succession beds of limestone, Argillaceous Limestone interbedded with marl, silt stone and clay stone beds. The upper part of the formation contains thick layers of clay light blue color of shale and green color sandstone beds which contain several types of floating foraminifera fossils such as (Sabbotina, Acannina, Morozovella Premurica, Eoglobigerina and Globonomalina) and species of benthonic fossils like (Lenticalina, Dorothina, Gavallina, Bolivina \& Gyrodina). Interfingering and interference appear within the upper part of the Kolosh and Sinjar formations. The thickness of this formation reaches in the study area about 500 meters. The depositional environment is a marginal marine environment. The clastic 
sediments of Kolosh Formation are of the type of sediments clastic flysch sediments that do not contain fossils which are destroyed by the effects of transportation that are the products of the erosion of Tanjero and older formation. The lower boundary of the formation is unconformable with the Tanjero Formation due to the absence of the Danian age. The age of this formation is considered Paleocene age (Omar, 2005). According to, the Kolosh formation extends from Dohuk, Rania, Sulaymaniyah, and Halabja area, as a belt separating the Red Bed Series and the sedimentary basin in which the Kolosh Formation is deposited. Kolosh and Tanjero formations have a highly geological importance, this is due to their wide extension in north and north-east of Iraq, in which weathering and erosion processes are affected by geological and climatic conditions over the long geological time, creating deep and complex depressions and valleys.

- Sinjar Formation (L.-M. Paleocene to E. Eocene): Sinjar Formation consists of massive thick layers of hard limestone at the upper part of the formation, which become thinner towards the top with the boundary of Gercus Formation due to decreases in the depth of the sedimentary basin. Sinjar formation has a succession of shale limestone interbedded with marly limestone graded downward which is called (gradual succession) (Ditmar, et al., 1971), of a yellowish to a grey color. The thickness of the formation is about (100) meters in the study area, the sedimentation environment is the shallow water reef, fore Reef and lagoonal environments. The upper limit of the formation is unconformable with the Gercus Formation.

- Gercus Formation (M. Eocene): It consists mainly of clastic friable clay which is called molasses sediments; it has a red color due to the oxidation environment in which they were deposited. The sedimentary facies of the Gercus Formation indicate that the sandstones were deposited in larger channel complexes that fed a mud-dominated slope. The massive sands are thought to originate from the gradual aggradation of sediment beneath steady flows. The Gercus Formation was deposited in a flowing system affected by turbidity currents in the marine environment, and this view was supported by the presence of the gluconite mineral in some layers of sandstone (Al-Mashaikie, et al., 2014). The thickness of the formation is about 100 meters in the study area. The lower limit of the formation is unconformable with the Sinjar formation, and the upper surface is conformable with the Avana Formation.

- Pilaspi Formation (L. Eocene): It consists mainly of succession of well-bedded strata of dolostone and dolomitic limestone rocks. The formation rocks contain chert nodules that are deposited in the joints, fractures and cracks that are formed by the effect of the folding processes. The thickness of the formation in the study area is about (200) meters (Jassim, 2006). The sedimentation environment of the Pilaspi Formation is Lagoon Environment, characterized by its high rigidity and resistance to the erosion and weathering that formed high ridges in the Kosret anticline, while the upper surface of Pilaspi Formation is unconformable with the lower surface of the Fat'ha Formation by the presence of a bed of conglomerates.

- Fat'ha Formation (M. Miocene): It is considered as an important formation in Iraq because of its wide extension and the variety of its beds in its succession. It consists of different sequences of evaporated rocks. The depositional environment of being confined to the closed Lagoon (Jassim and Goff, 2006). A layer with a thickness of 5 meters of conglomerates is considered as a surface of unconformity between the lower surface of the Fat'ha Formation and the upper surface of the Pilaspi Formation.

- Injana Formation (L. Miocene): It was deposited in a river environment, consisting of many sedimentary cycles, in each one there are two main sedimentary facies (Al-Juboury, 2009). One of coarse grain that appear as layers with a thickness ranges 3-5 meters consisting of silt and clay, and the second facies of sediment fine grains that appears as layers with a thickness of 2-3 meters of clay and mud layers. The outcrops of this formation on the surface of the study area show a different 
thickness depending on the geomorphology of the area and the variety of the erosion processes that led to the removal of most layers of this formation.

\section{Results and Discussion}

\subsection{Analysis of the Rock Slopes Stability}

Direct Shear Test is performed to identify and determine the degree of soil cohesion and the internal friction angle of the soil as shown in (Fig. 5), the value of the friction angle is equal to $25^{\circ}$ and the value of the cohesion is equal to $50 \mathrm{~K} \mathrm{P}$ as in ASTM D3080 / D3080M which is found in a laboratory test. The degree of soil cohesion can be used to analyze all types of rock collapse. The value of internal friction angle is of great importance in the studying of the type failures, such types like plane sliding and wedge sliding because of locating Shiranish Formation under the Kometan Formation that causes a collapse and sliding in the layers of the Kometan Formation.

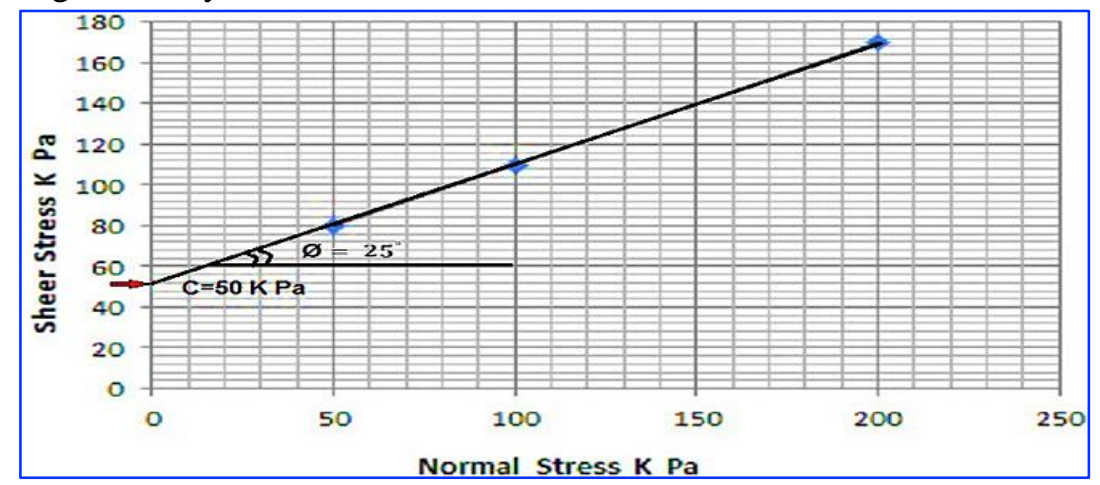

Fig. 5. The relationship between shear stress and normal stress

The rock slope stability was studied to analyze their stability according to the stations selected in the exposed rock formations in the study area (Fig. 1) and (Table 3).

Table 3. Geological and engineering coefficients of the stations in the study area

\begin{tabular}{cccc}
\hline $\begin{array}{c}\text { Station } \\
\text { No. }\end{array}$ & Formation & $\begin{array}{c}\text { Internal friction } \\
\text { angle }\end{array}$ & $\begin{array}{c}\text { Slope Angle } \\
\text { Dip direction/ dip angle }\end{array}$ \\
\hline St.1 & Kometan & 25 & $255 / 80$ \\
St.2 & Shiranish & 42 & $260 / 80$ \\
St.3 & Kometan & 25 & $270 / 85$ \\
St.4 & Kometan & 25 & $210 / 30$ \\
St.5 & Kometan & 25 & $270 / 80$ \\
St.6 & Kometan & 25 & $230 / 90$ \\
St.7 & Kometan & 25 & $210 / 60$ \\
St.8 & Kometan & 25 & $180 / 35$ \\
St.9 & Kolosh & 40 & $160 / 53$ \\
\hline
\end{tabular}

\subsubsection{Station 1}

The slope stability of station1 has been analyzed, which is located on the right side of the road between Dukan-Qwaisanjaq, Erbil City, where the limestone of the Kometan Formation (Turonian), the discontinuities were spatially dropped in poles and geometrically classified according to its relation to the imaginary tectonic axes. The (hkl) system, which is usually caused by local stresses in different directions and to the (hko<b) system as evidence of the effect of tectonic stress towards the northwest- 
southeast perpendicular to the general stress that caused the folding in the area. This station is characterized by the possibility of rock falling from the slope in the same direction of the slope (Day Lighting) because the angle of internal friction is less than the angle of slope, which makes it stand out in the face of the slope and because of the presence of the joints (J1) and (J2), which act as the side and front movement with the possibility of erosion of the lower rocks of the formation of Kometan, this helps to get the process of rock falls (Fig. 6). A normal fault at a station (1) was identified in the Kometan Formation, where The hanging wall moves downward wall relative to the foot wall was determined by the lamellar notches and the level of the fault as a slope angle / inclination value was 285/47.

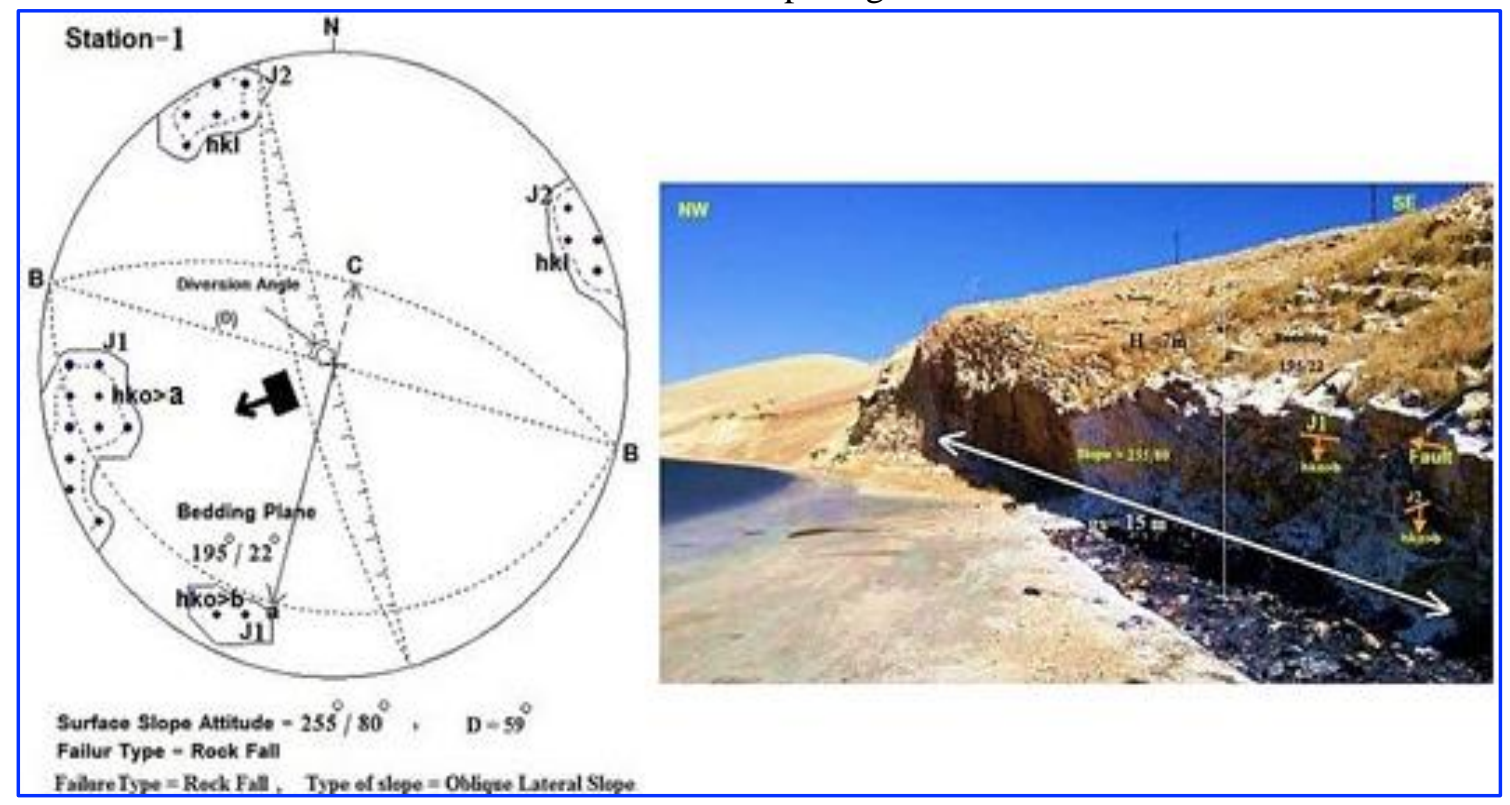

Fig. 6. Stereographic projection and image of station-1

\subsubsection{Station 2}

It is located on the right side of the road (Fig. 7) within the Shiranish Formation (MastrichtianCampanian) which excavated along the face of the slope. This station is characterized by the occurrence of rock falls and plane sliding that stands out in the face of the slope and the friction angle of the sliding surfaces is less than the angle of the general slope. The (J1) Joint set, which acts as a side starting surfaces and the (J2) Joint, which acts as a front starting surface, help to cause a plane sliding at this station when the cohesion about the fractures is equal to zero, as well as the weathering and erosion of the rock masses in the lower layers of the slope face to facilitate the process of rock falling. The Joints were spatially dropped in polar form and geometrically classified according to their relation to the imaginary tectonic axes into the (hko<a) system as evidence of the effect of tectonic stress towards the northeast-southwest proportional to the general stress that caused the folding in the area. The veins were observed at the second station within the Shiranish Formation and classified into the hko<b system, indicating a change in the direction of stress from the perpendicular to the fold axis to the parallel direction of the axis (Fig. 8). 


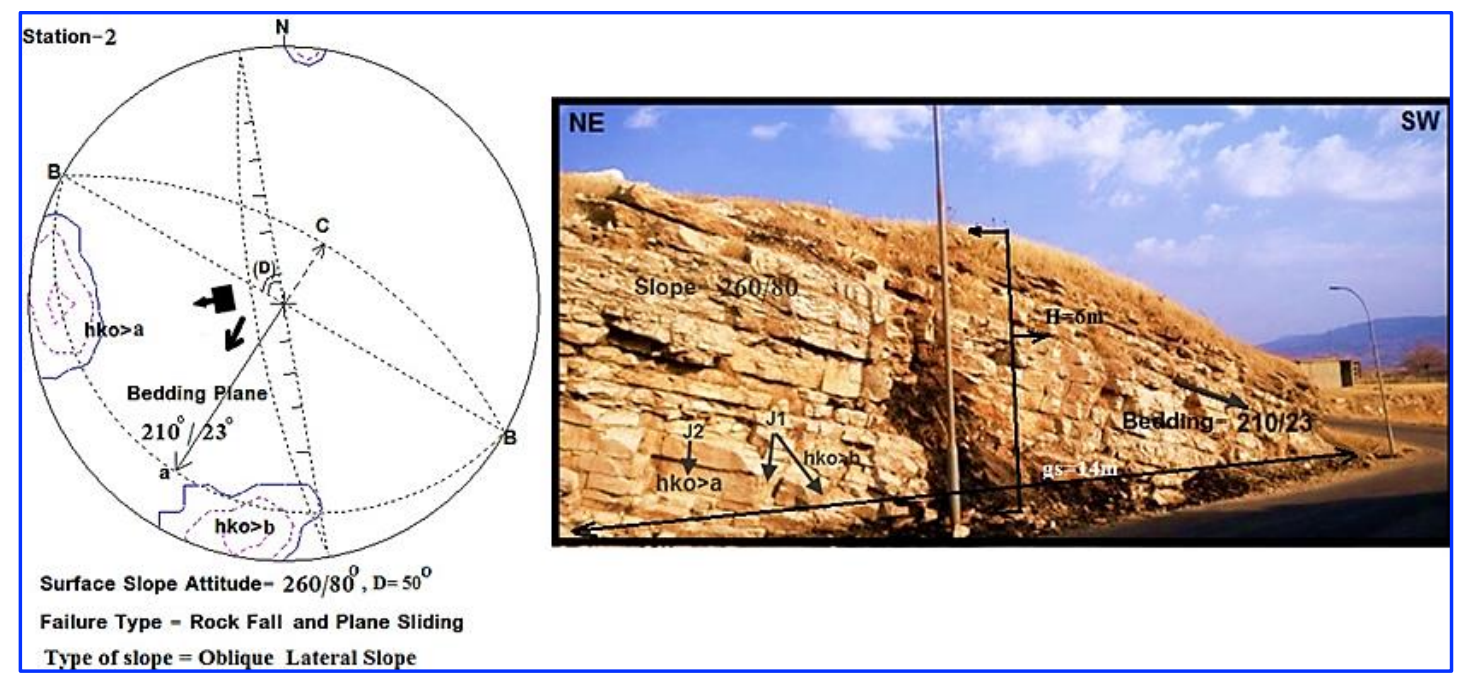

Fig. 7. Stereographic projection and image of station 2

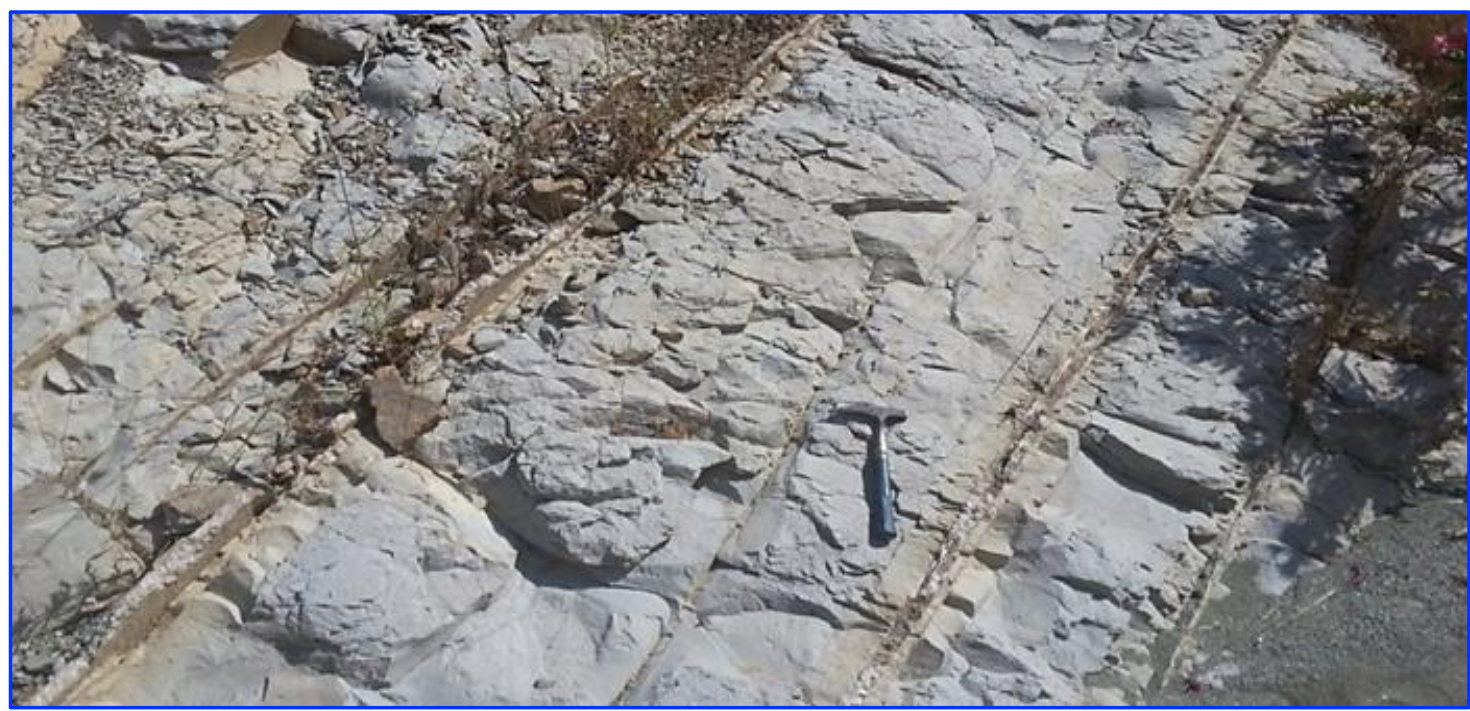

Fig. 8. Veins of calcite within the Shiranish Formation in station -2

\subsubsection{Station 3}

It is located on the right side of the road, the Kometan Formation rocks, consisting of limestone layers, with steep slopes directly overlooking the eastern side of the road linking between Dukan-Erbil, and the strike line of the layers is almost perpendicular to the road. The exposed rock body along the road leads to rock fall, especially through the exposed rocks are rich in the system of Joints (J1) and (J2). The slope analysis was performed at Station-3, on the slope of the Dip Slope of the barrier. The slope at this station represents the face of the slope (Fig. 9). A side starting surface leads to the occurrence of rock fall. There is a part of the slope, its strike is parallel to the strike of the bedding, its type of hanging slope, which leads to Toppling rocks failure, and the cohesion about the fractures comes to zero degrees.

The joints were spatially projected and polarized according to their tectonic axes is bisect (hko>a) joint system around the tectonic axis as evidence of the effect of tectonic stress perpendicular to the fold axis, which is northeast-southwest proportional to the general stress that caused the fold in the area. 


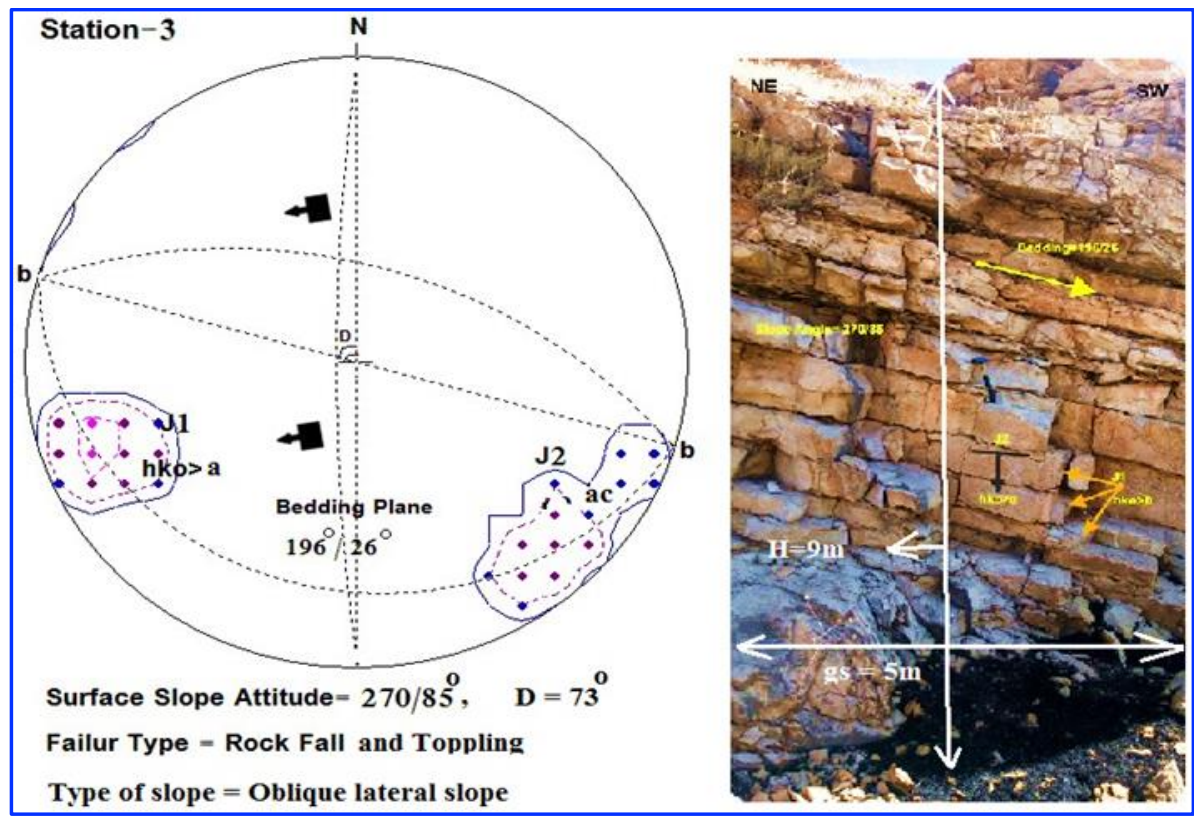

Fig. 9. Stereographic projection and image of station-3

\subsubsection{Station 4}

It is located to the right of the main street as well, but it is located on a strong turn in the main street which makes its location a great danger to the safety of the main street through the occurrence of Toppling falls due to the slope angle at the same direction of the bedding plane, consisting of layers of limestone of Kometan formation where the bedding plane is clear as well as the presence of joints (J1) and (J2) that act as lateral starting surfaces. Due to the impact of weathering, erosion, excavation and road maintenance and construction operations, this leads to the process of Toppling falls along the main road (Fig. 10).

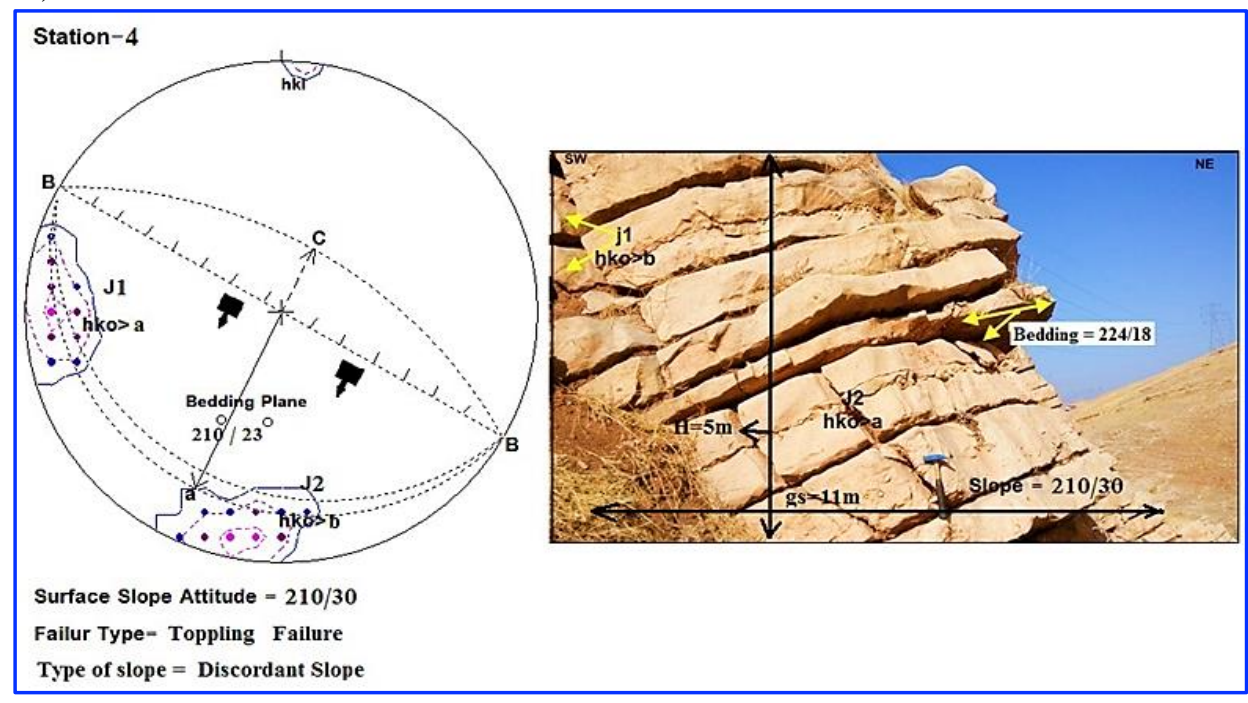

Fig. 10. Stereographic projection and image of station 4

\subsubsection{Station 5}

The fifth station is located to the right of the main street leading to Shaqlawa- Erbil, where the formation of Komitan is excavated, which consists of solid limestone rocks, forming high barriers with steep slopes directly overlooking the eastern side of the road. The exposed rock body along the road leads to topling facing the dip slope especially through the fractural dense rock of the slope rich in Joints 
(J1) and (J2). The Joints were spatially dropped as poles and geometrically classified according to their relation to the imaginary tectonic axes to the hko system in which the tectonic axis b is bisect the acute angle and as evidence of the effect of tectonic stress in a parallel direction to the fold axis. In addition to the presence of the (ac) group as evidence of the stresses in a direction perpendicular to the axis of the fold with the presence of the hkl system, indicating the presence of local stresses in different directions (Fig. 11).

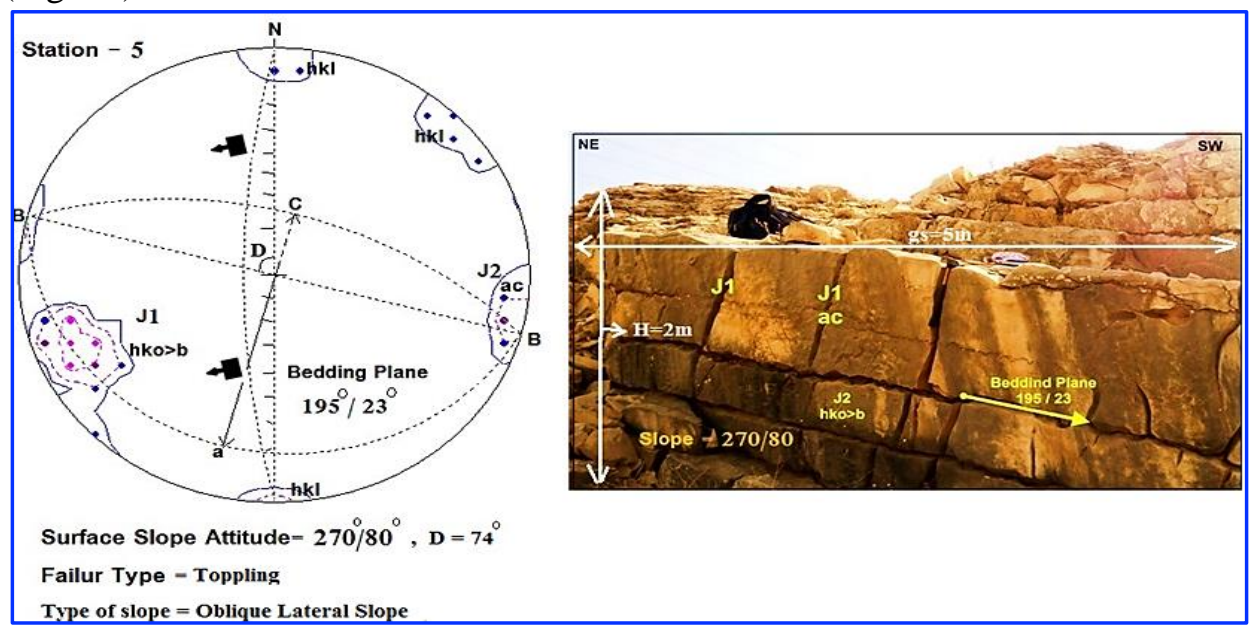

Fig. 11. Stereographic projection and image of station 5

\subsubsection{Station 6}

It is located on the right side of the road where the excavation of the Kometan Formation consists of hard limestone rocks, in the form of high barriers with steep slopes directly on the east side of the main road. The striking line layers almost parallel with the extension of the road.

The rock detector body and the nature of the geometric relations between the attitude of Join (J1) and (J2). This leads to the occurrence of rockfall, especially since the rocks of the detector are rich in groups of high-angle joints with attitudes of bedding plane (Fig. 12). This rock fall sometimes exceeds the shoulder of the road and causes dangers for road walkers.

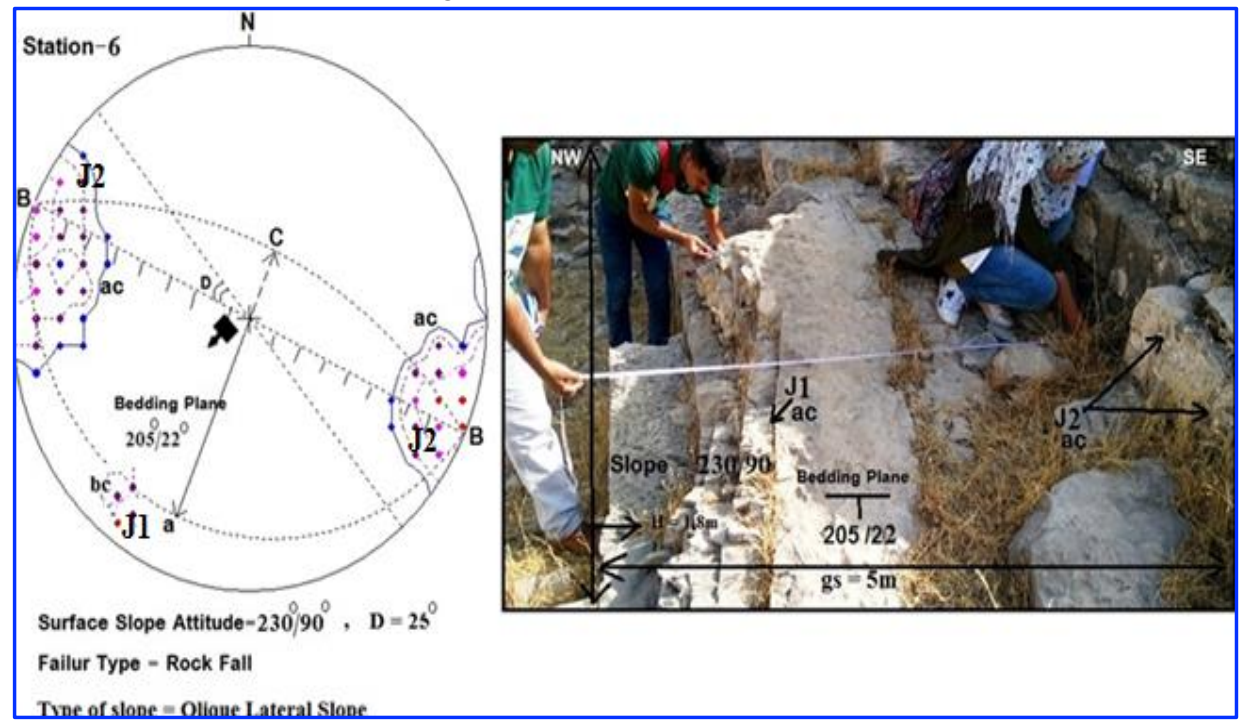

Fig. 12. Stereographic projection and image of station 6 


\subsubsection{Station 7}

It is located just on the right side of the road which is Kometan Formation, with steep slopes facing directly the east side of the main road and strike of the layers almost parallel with the extension of the road. The exposed rock body and the nature of the geometric relations between the attitude of Joints (J1) and (J2). This leads to the occurrence of rock fall, especially through the rocks which are rich in groups of high-angle joints with bedding plane (Fig. 13). The Joints were spatially dropped as poles and geometrically classified according to their relationship with the tectonic axes of the ac and bc groups as evidence of the stresses in direction perpendicular and parallel to fold axis respectively.

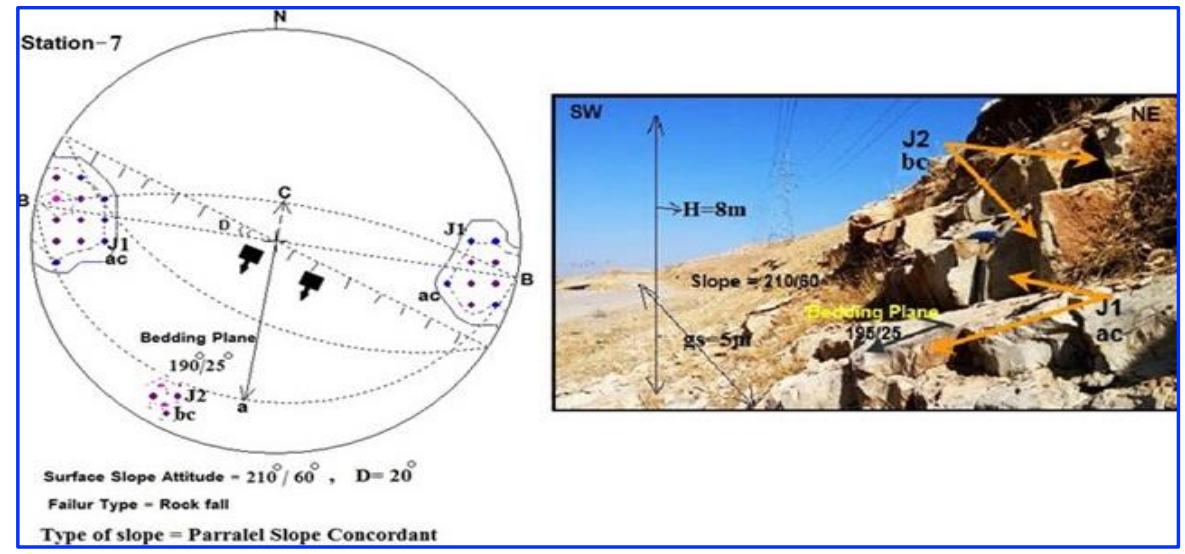

Fig. 13. Stereographic projection and image of station 7

\subsubsection{Station 8}

It is located on the right side of the road, where the Kometan Formation is consisting of solid limestone rocks excavated on the side slope. The slope facing the road is 25 degrees on the eastern side of the main road. The bedding plane of the layers is opposite to inclination where the strike is mostly perpendicular to the side road. The shape of the slope and the nature of the engineering relations between the bedding plane and Joint (J1) and (J2) occurrence of rock fall and toppling when weathering and erosion processes are active and effective. The Joints were spatially dropped as poles and geometrically classified according to their relationship with its imaginary tectonic axes into the hko>a and hko>b system in two positions as evidence of the effect of tectonic stress parallel and perpendicular to the axis of the fold (Fig. 14).

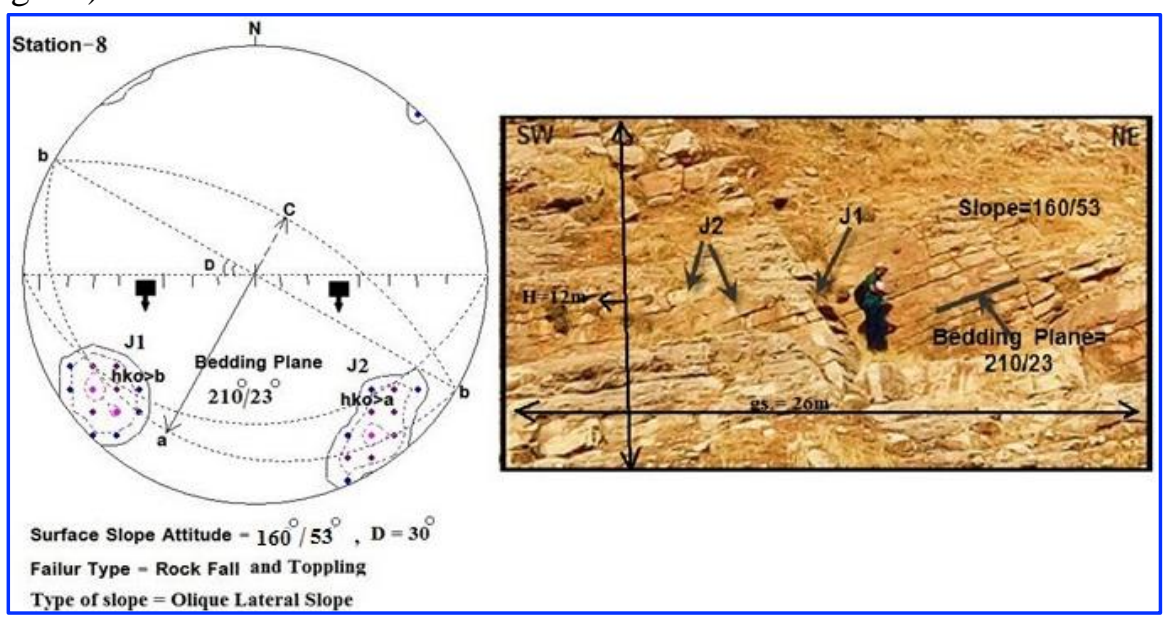

Fig. 14. Stereographic Projection and Image of Station 8 


\subsubsection{Station 9}

It is located at a distance of about 50 meters from the right side of the road linked between Dokan and Erbil on the slope with a degree of 53. There are two joints, the hko>a facing the slope of incline and the other joint is hko>a which is almost perpendicular to the surface of the bedding. The presence of these two joints leads to a rock fall along the surface of the slope. The Joints were spatially dropped as poles and geometrically classified according to their relationship with its imaginary tectonic axes into the (hko>a) system in two positions as evidence of the effect of tectonic stress perpendicular to the axis of the fold (Fig. 15).

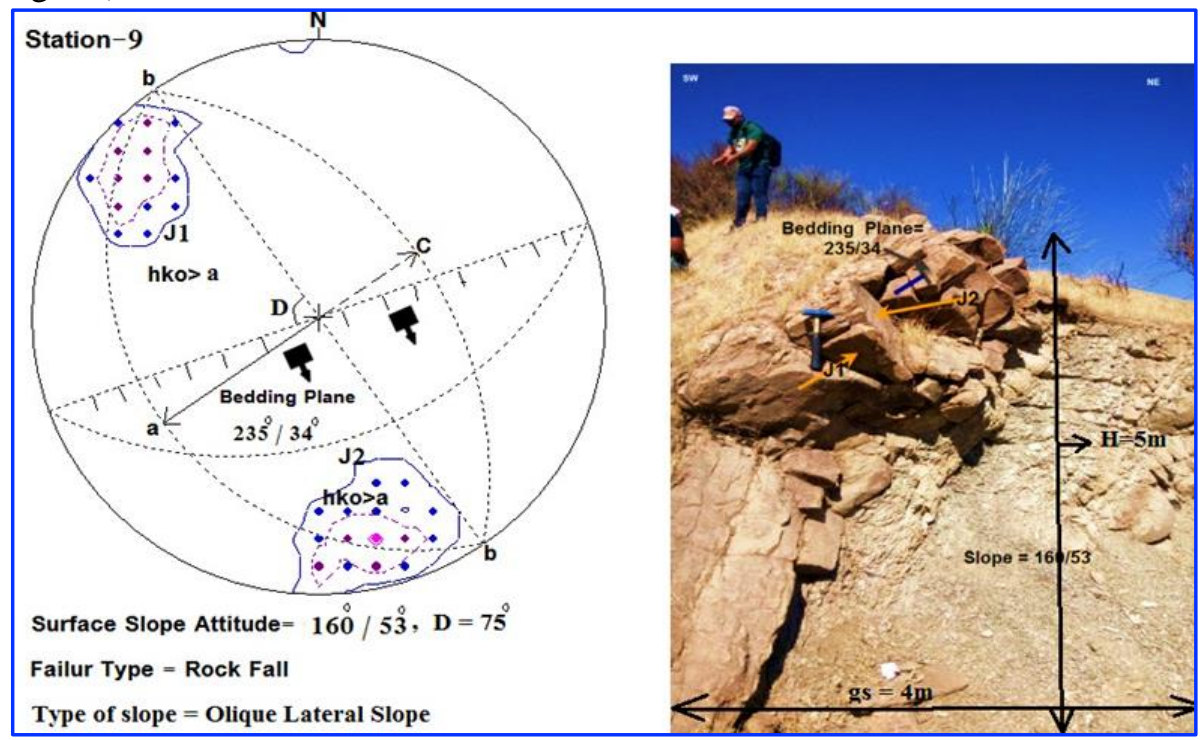

Fig. 15. Stereographic projection and image of station 9

\section{Conclusions}

The slope of the stations in the studied area oblique lateral slopes and one of them is concordant the main failure modes are rock fall, toppling, and probably the failure type in the future may be planner sliding due to the angle of the friction comes to zero degree. To control the instability of the rock slopes, stopping the rock falls on the slopes and preventing them from reaching the approaches the main street, we suggest that one of the following proposals be made, work steps or stands depending on the height of the ramp, the runway height can be from (1.5-2.0) meters and a width (2-3) meters and an inclination angle (40-50) degrees, to prevent the process of rock fall or any collapse from the slope, and it may be more than one runway with the same specifications above when the height of the slope exceeds more than two meters. This procedure is permanent and in the future allows for an expansion of the public street. The hkl system, which is usually caused by local stresses in a different direction to the hko $>\mathrm{b}$ and hko $>$ a system as evidence of the effect of tectonic stress towards the northwest-southeast perpendicular to the general stress that caused the folding in the area and hko>a developed due to northeastward stresses that perpendicular to fold axis. As a side starting surface leads to the occurrence of rock fall and toppling, as well as the weathering and erosion of the rock masses in the lower layers of the slope face to facilitate the process of rock falling. Due to the impact of weathering, erosion, excavation and development of the main road, this leads to the process of rock falls and toppling along the main road. We suggest completing the study and analysis of the slope failure along the road linking between Dokan and the city of Koysanjaq to avoid the risk of failure by taking the necessary measures to protect the road or when building civil and engineering facilities. 


\section{Acknowledgements}

The author would like to thank Prof. Dr. Mohammad Rashed Abood for his scientific notice to complete the current study. Also, the author would like to thank Mr. Luis Sanchez, Senior Editor of GEOrient 9.5 software former Creates orientation plots based on stereographic data, who developed and make this program free on the Internet for the purpose of benefiting from specialists and researchers in this field. The authors are very grateful to the Editor in Chief Prof. Dr. Salih M. Awadh, the Secretary of Journal Mr. Samir R. Hijab. and the Technical Editors for their great efforts and valuable comments.

\section{References}

Al-Khafaf, A. O., 2005. Stratigraphy of Kometan Formation (Upper Cretaceous) in Dokan- Endezah area, NEIraq. M.Sc. thesis (unpublished), University of Mosul, 79pp.

Al-Mashaikie, S. Z. A. K., Abbas, T., Al-Azzawi, A., Kadum, A. K., 2014. Depositional Environment of the Gercus Formation in Jabal Haibat Sultan, NE Iraq; New Sedimentological Approach, Iraqi Journal of Science, 55(2A), 471-483.

Al-Dulaimi, S. I., Mahdi, T. H., 2008. Mid-Cretaceous radiolarians from The Balambo Formation Ne-Iraq, Iraqi Journal of Science, 49(2), 132-139.

Al-Juboury, A. I. A., 2009. The Upper Miocene Injana formation of Iraq: In sight on provenance history, Arabian Journal of Geoscience, 41(29), 338- 364.

Anon, 1972. The Preperation of Maps and Plans in Terms of Engineering Geology, QJEG 5, 293- 382pp.

Asaad, I. S., 2014. Sedimentology and stratigraphy of the Kometan Formation (Upper Turonian-Lower Campanian), in the Kometan village-imbricated Zone Iraqi Kurdistan Region. Unpublished Higher Diploma Dissertation, Salahaddin University-Erbil.

ASTM D3080 / D3080M - 11, Standard Test Method for Direct Shear Test of Soils Under Consolidated Drained Conditions.

Balaky, S. M., Asaad, I. S., Al-Juboury, A. I., 2016. Facies analysis and sequence stratigraphy of Kometan Formation (Upper Cretaceous) in the imbricated zone, northeastern Iraq. Arabian Journal of Geosciences, $9(20), 1-17$.

Ditmar, V., Iraqi-Soviet Team, 1971. Geological Conditions and Hydrocarbon Prospect of the Republic of Iraq (Northern and Central Parts) Manuscripts Report, INOC Library, Baghdad.

Dunnington, H.V.,1953. Thickness and facies variation in Upper Cretaceous (Upper Campanian - Mastrichtian) of Northern Iraq. Manuscript Report, INOC Library, Baghdad.

Hoek, E., Bray, J. W., 1981. Rock Slope Engineering, $3^{\text {rd }}$ edition, (institution of mining and metallurgy, London, $358 \mathrm{pp}$.

Hawkins, A. B., 1986. Rock description, geological society, engineering geology, Special Publication, (2), 59-72.

Jassim, S. Z., Goff, J. C., 2006. Geology of Iraq. Published by Dolin, Prague and Moravian Museum, Brno, 341pp.

Maerz, N.H., 2000. Highway Rock Cut Stability Assessment in Rock Masses Not Conductive to Stability Calculation. 51st Annual Highway Geology Symposium, Washington, 249-259 pp.

Malak, Z. A., 2015. Sequence stratigraphy of Shiranish Formation in Dokan area, Northern Iraq. Arabian Journal of Geosciences, 8(11), 9489-9499.

Omar, A. A., 2005. An Integrated Structural and Tectonic Study of the Bina Bawi-Safin-Bradost Region in Iraqi Kurdistan. PhD Thesis, Sallahdeen University.

Qader, R. M., \& Arab, S. H., 2020. Engineering geological assessment of the rock slope stability along the proposed lerabire road in the Mergasur City, Kurdistan, Iraq. The Iraqi Geological Journal, 65-82.

Qader, R. M., Syan, S. H. A., 2021. Rock slope stability assessment along Rawanduz main road, Kurdistan Region. The Iraqi Geological Journal, 79-93.

Ward, A. H.,8. Geometry and structural history of Khalakan anticline north eastern Iraq. Ph. D. thesis, Baghdad University, Baghdad, Iraq: 150 pp. 